\title{
ХРОНІЧНА ПОСТТРАВМАТИЧНА ЕНЦЕФАЛОПАТІЯ. ПОГЛЯД НА ПРОБЛЕМУ
}

\section{Хронічна посттравматична енцефалопатія. Погляд на проблему}

\section{3. В. Салій}

Тернопільський національний медичний університет імені І. Я. Горбачевського МОЗ України

Резюме. Хронічна травматична енцесралопатія (XTE) - унікальна нейродегенеративна таупатія - вперше описали в боксерів, а згодом, у спортсменів контактних видів спорту, військових ветеранів та цивільних, які піддавалися повторним легким черепно-мозковим травмам.

Мета дослідження - проаналізувати світовий досвід останнього десятиліття у дослідженні поширеності, фракторів ризику, патогенезу та діагностики хронічної травматичної енцефралопатії.

Матеріали і методи. Здійснено аналіз доступних інфрормаційних ресурсів мережі «Internet», іноземних фрахових видань, медичної бази даних MEDLINE/PubMed за останні десять років. Застосовано метод інорормачійного пошуку та аналітико-порівняльний.

Результати. Експериментальні та клінічні роботи останнього десятиліття спрямовані на вирішення численних проблем, зокрема встановлення поширеності XTE, фракторів ризику, основних патогенетичних механізмів, удосконаленні морорологічних та клінічних критеріїв, спробах класифрікувати XTE, пошуку біомаркерів та специфрічних нейровізуальних критеріїв. Клінічно для патології властивіпрогресуючікогнітивні (пам'ять, виконавча диссрункція, візуально-просторова дисфрункція) й поведінкові (збудливість, агресія) розлади, зміни настрою (депресія, суїцидальність) та рухові порушення (диссрагія, брадикінезія, тремор, ригідність, порушення ходи, падіння тощо). Триває пошук консенсусу щодо клінічної класифрікації ХTЕ. Морфологічно XTE характеризується процесами накопичення фоосфорильованого тау (p-mау) у верхівках і навколосудинних ділянках, мікрогліозу та астроцитозу, що призводить до прогресуючої нейродегенерації. Ураження зазнають в основному лобна, скронева та потилична частки. Встановлено роль контактних видів спорту, віку, в якому було оттимано першу черепно-мозкову травму (критично 9-12 років), тривалості спортивної кар'єри.

Висновки. Незважаючи на майже столітню історію вивчення XTE, з часом кількість питань, які потребують вирішення, - зростає. Перспективним є пошук діагностичних критеріїв, які дозволять не лише прижиттєво підтвердити діагноз ХTE, але і встановити маркери (нейрональної, аксональної та астрогліальної травм), що прогнозуватимуть ризик розвитку нейродегенеративної патолосії після черепно-мозкової травми.

\section{Chronic post-traumatic encephalopathy. A look at the problem}

\section{Z. V. Salii}

I. Horbachevsky Ternopil National Medical University e-mail: saliy@tdmu.edu.ua

Summary. Chronic traumatic encephalopathy (CTE) is a unique neurodegenerative tauopathy first described in boxers but more recently described in a variety of contact sport athletes, military veterans, and civilians exposed to repetitive mild traumatic brain injury.

The aim of the study - to analyze the world experience of the last decade in the study of prevalence, risk factors, pathogenesis and diagnosis of chronic traumatic encephalopathy.

Materials and Methods. Available resources in the Internet, foreign professional publications, MEDLINE/PubMed medical databases of the last ten years were analyzed. The method of information search and analytical-comparative method were applied.

Results. Experimental and clinical works of the last decade were aimed at solving numerous problems such as defining the prevalence of CTE, risk factors, basic pathogenetic mechanisms, improving morphological and clinical criteria, attempts to classify CTE, search for biomarkers and specific neurovisual criteria. Clinically, there are characteristic progressive deficits in cognition (memory, executive dysfunction), behavior (explosivity, aggression), mood (depression, suicidality), and motor function (dysarthria, dysgraphia, bradykinesia, tremor, rigidity, gait disturbance, falls, and/or other features of parkinsonism). The search for consensus on the clinical classification of CTE continues. Morphologically, CTE is characterized by a focal perivascular deposits of p-tau in the neocortex, microgliosis and astrocytosis, which leads to progressive neurodegeneration. The frontal, temporal and parietal lobes are often affected. The role of contact sports, the age the first traumatic brain injury was received (critically 9-12 years), the duration of a sports career has been determined.

Conclusions. Despite the almost century-long history of studying CTE the number of issues to be addressed is growing. It is promising to search for diagnostic criteria that will not only confirm the diagnosis of CTE in life, but also to determine markers (neuronal, axonal and astroglial trauma) that will predict the risk of neurodegenerative pathology after traumatic brain injury. 
Ключові слова: хронічна травматична енцефралопатія; таупатія; критерії діагностики.

\section{ВСТУП}

Черепно-мозкова травма (ЧМТ) $€$ основною причиною смертності та захворюваності в усьому світі. Легка ЧМТ (струс та забій головного мозку легкого ступеня) унаслідок удару або вибуху $є$ найпоширенішими типами ЧМТ у цивільних та військових умовах - щорічно показник сягає 42 млн випадків [1]. Все більше дослідників та клініцистів вказують на те, що легка ЧМТ може призвести до стійких наслідків, а в окремих випадках - до прогресуючої нейродегенерації та хронічної травматичної енцефралопатії (ХTE) [2]. ХTE - унікальна нейродегенеративна таупатія - вперше описали у боксерів, а згодом - у спортсменів контактних видів спорту, військових ветеранів та цивільних, які піддавалися повторним легким ЧМТ [1].

Метою дослідження було проаналізувати світовий досвід останнього десятиліття у дослідженні поширеності, фракторів ризику, патогенезу та діагностики хронічної травматичної енцефралопатії.

\section{МАТЕРІАЛИ I МЕТОДИ}

Здійснено аналіз доступних інфрормаційних ресурсів мережі «Internet», іноземних фрахових видань, медичної бази даних MEDLINE/PubMed за останні 10 років. Застосовано метод інорормаційного пошуку та аналітико-порівняльний.

\section{РЕЗУЛЬТАТИ Й ОБГОВОРЕННЯ}

H. Martland у 1928 р. описав тяжкі нервово-психічні симптоми у групі боксерів, назвавши їх «dementia pugilistica», що можна вважати початком вивчення даної патології [3]. Станом на 2019 р. не існувало узгоджених критеріїв діагностики ХTE, хоча запропоновано 5 варіантів [4-8]. Враховуючи особливості патології, реальна поширеність XTE залишається невідомою. У роботі D. R. Weir [9] повідомлено, що поширеність деменції серед колишніх гравців національної фрутбольної ліги старших 50 років у 5 разів вища, ніж у популяції. ХTE діагностували у 32 \% з 1721 проаналізованих випадків у осіб, які займалися контактними видами спорту [10]. Автори обґрунтовують необхідність та важливість подальших перспективних досліджень.

Експериментальні дослідження спрямовані на встановлення провідних патогенетичних ланок ХTE. Точний механізм, що дозволяє пояснити як повторні чМТ призводять до нейродегенерації, ще не встановлений [11]. Припускають провідну роль ексайтотоксичності [12], активації мікроглії [13].
Key words: chronic traumatic encephalopathy; tauopathy; diagnostic criteria.

Повторна ЧМТ призводить до ХТЕ шляхом тауолігомеризації після аксональної дефрормації та мікротубулярної дестабілізації [14].

Низка досліджень надає докази того, що перетворення тау в аномально фоссрорильовані протеотоксичні проміжні продукти (р-тау) може бути частиною процесу, який ініційований однією ЧМТ та посилюється повторними. A. D. Bachstetter et al. (2020) [15] в експерименті отримали переконливі докази модисрікації тау-фросфорилювання при легкій ЧМТ.

Активація рецепторів NMDA унаслідок механічного ушкодження або нейродегенерації також призводить до деградації тау-протеїну шляхом протеолізу кальпаїном та каспазами [16]. Хінолінова кислота, яку виявляють у $\beta$-амілоїдних бляшках, також здатна активувати NMDA- рецептори, стимулюючи тим самим гіперфоссрорилювання тау-протеїну. Інший можливий шлях - генерація вільних радикалів, мітохондріальна дисорункція, дисбаланс кальцію [17].

Морфологічно, для XTE характерні процеси накопичення фосорорильованого тау (р-тау) у верхівках і навколосудинних ділянках, мікрогліозу та астроцитозу, що призводить до прогресуючої нейродегенерації. Ґрунтуючись на закономірностях прогресування ХTE, виділяють 4 стадії патологічного процесу $[17,18]$.

У І стадії виявляють таувмісні нейрофрібрилярні клубочки у периваскулярних просторах у глибинних звивинах лобних часток.

В II стадії нейрофрібрилярні клубочки виявляють на поверхні кори, locus coeruleus та базальному ядрі Мейнерта. Патоморфологічно та нейровізуалізаційно діагностують розширення бічних шлуночків, патологію прозорої перетинки з або без її френестрації.

На III стадії патологічний процес поширюється на скроневі, тім'яні частки та острівець. Діагностують легку атрофрію лобних та скроневих часток.

Ha IV стадії зменшення маси мозку є «драматичним», виражена атрофрія лобних, медіальних скроневих часточок, а також переднього таламусу.

Однак враховуючи вибірковість розвитку XTE, постало питання дослідження можливих фракторів ризику. Встановлено роль контактних видів спорту [19], віку в якому було отримано першу ЧМТ [20], тривалості спортивної кар'єри. Період від 9 до 12 років було визначено як ключовий у дозріванні сірої та білої речовини й фрормуванні гіпокампу та мигдалини [21, 22]. J. M. Stamm et al. [23] встановили, що молодший вік отримання ЧМТ корелював із зменшенням об'єму лівого таламуса та змінами в архітектоніці мозолистого тіла. V. Schultz et al. [24] отри- 
мали аналогічні достовірні $(p=0,03)$ залежності 3 кількістю років, проведених у професійному спорті.

Чіткої генетичної схильності не встановлено, однак наявність гена АpoE4, найбільш відомого фрактора ризику хвороби Альцгеймера [25], корелювала з тяжчим когнітивним дефіцитом та більш затяжним періодом відновлення після ЧМТ [26]. І навпаки, ген АроЕ3 може надавати нейропротекцію навіть за наявності XTE [27]. Іншим запропонованим захисним фрактором є когнітивний резерв, виміряний преморбідним IQ [26]. Тривають дослідження 3 встановлення ролі генів білка тау, асоційованого з мікротрубочкою, програминуліну (GRN) та C9ORF72 [5].

Jordan et al. [28] одними з перших спробували систематизувати клінічні характеристики захворювання. Вони розділили клінічні появи ХTE на 3 сорери: поведінкову, когнітивну та рухову. До розладів поведінкової сорери належать: агресія, депресія, апатія, імпульсивність, марення, включаючи параною та суїцидальність. Когнітивний домен включає зниження уваги та здатності до концентрації, дефріцит пам'яті, дефіцит виконавчої фрункції, візуально-просторову дисорунцію, розлади мови та деменцію.

Рухові розлади проявлялися дизартрією, порушенням ходи, атаксією та дискоординацією, спастичністю та ознаками паркінсонізму (тремор).

На основі цих клінічних особливостей Jordan et al. [28] було визначено 4 діагностичні підтипи XTE, а саме: «достовірний» (за наявності патологоанатомічного підтвердження типових клінічних проявів) та за різних комбінацій клінічних проявів «ймовірний», «можливий» та «малоймовірний». Вказані критерії не здобули поширення та зазнали критики [29].

P. H. Montenigro et al. [6], ґрунтуючись на аналізі численних літературних джерел, запропонував альтернативний клінічний термін - синдром травматичної енцефралопатії, який не потребує урахування даних патологоанатомічного дослідження.

Симптоми було об'єднано у 3 групи (5 - загальних критеріїв, 3 - клінічних та 9 - підтримувальних).

І. Загальні критерії XTE.

Для постановки діагнозу XTE необхідна наявність наступних 5 критеріїв:

1. Багаторазові травми голови в анамнезі, які розрізняються за видом травми (а) і джерелом впливу (б):

а) вид травми:

- легка ЧМТ або струс головного мозку. За відсутності в анамнезі інших повторних травм головного мозку необхідна наявність як мінімум чотирьох легких ЧМТ або струсів головного мозку;

- середньої тяжкості/тяжка ЧМТ. За відсутності в анамнезі інших повторних травм головного мозку необхідна наявність як мінімум двох таких травм;
- безсимптомна (subconcussive) травма голови.

б) джерело впливу:

- заняття контактними видами спорту підвищеного ризику (в тому числі боксом, американським фрутболом, хокеєм на льоду, регбі, боротьбою, футболом) протягом як мінімум 6 років, з яких 2 на рівні не меншому, ніж у спортивному коледжі;

- військова служба (в тому числі бойова чи небойова дія вибуху);

- інші значні повторні удари по голові (в тому числі домашнє насильство, професійна діяльність, наприклад вибивання дверей поліцейськими);

- для середньої тяжкості/тяжкої ЧМТ: будь-яка причина (наприклад дорожньо-транспортна пригода).

2. Виключення іншого неврологічного розладу, що має подібні клінічні прояви (включаючи залишкові симптоми одиничної ЧМТ або персистуючий постконтузійний синдром), хоча можливий супутній діагноз медикаментозної залежності, посттравматичного стресового розладу, афективних/тривожних розладів або іншого нейродегенеративного захворювання.

3. Клінічні прояви зберігаються не менше 12 місяців.

4. Наявність на момент огляду не менше однієї із трьох клінічних ознак.

5. Наявність як мінімум двох додаткових ознак.

II. Основні клінічні ознаки ХTЕ.

Необхідна наявність хоча б 133 наступних критеріїв:

1) когнітивні порушення, виявлені з анамнезу або в ході проведення нейропсихологічних тестів, що дозволяють оцінити епізодичну пам'ять, регуляторні фрункції і/або увагу;

2) поведінкові порушення, такі, як запальність, фрізичне та/або словесне насильство, виявлені 3 анамнезу або при огляді;

3) афрективні порушення, такі, як смуток, депресія і/або відчай, виявлені з анамнезу або при огляді.

III. Додаткові клінічні ознаки ХTЕ.

Необхідна наявність хоча 62 наступних 9 критеріїв:

1) імпульсивність: поява пристрасті до азартних ігор, підвищеної або незвичайної сексуальної активності, зловживання ліками, шопоголізм тощо;

2) тривога: тривожний настрій, збудження, обсесивна, компульсивна або обсесивно-компульсивна поведінка, виявлені 3 анамнезу або при огляді;

3) апатія - втрата інтересу до колишніх захоплень, мотивації та емоцій або зниження цілеспрямованої поведінки, виявлені 3 анамнезу або при огляді;

4) параноя: маячні переконання підозри в чомусь, переслідуванні кимось і/або необґрунтовані ревнощі, виявлені з анамнезу або при огляді; 
5) схильність до суїциду: суїцидальні думки або спроби, виявлені з анамнезу або при огляді;

6) головний біль: хронічний виражений головний біль не рідше одного разу на місяць упродовж не менше 6 місяців;

7) рухові розлади: дизартрія, диссрагія, брадикінезія, тремор, ригідність, порушення ходи, падіння й інші ознаки;

8) погіршення стану: прогресування симптомів і ознак, зафріксоване при повторних (не менше ніж через рік) тестуваннях і клінічних оглядах;

9) латентний період маніфестації: як правило, перші клінічні ознаки з'являються як мінімум через два роки після ЧМТ [30].

Проаналізувавши 202 випадки, Р. Н. Montenigro et al. [6] поділили XTE на 4 варіанти (за домінуючою клінічною ознакою):

1. Поведінковий/афективний варіант ХTЕ. Наявність у пацієнта поведінкових/афективних порушень і відсутність когнітивних.

2. Когнітивний варіант XTE. Наявність у пацієнта когнітивних порушень і відсутність поведінкових/афективних.

3. Змішаний варіант ХTE. Наявність у пацієнта когнітивних і поведінкових/афективних порушень.

4. В якості окремого виділено варіант XTE 3 деменцією, коли прогресуюче порушення когнітивних функцій призводить до зниження повсякденної активності. Пацієнти втрачають здатність до самообслуговування і стають фрункціонально залежними від інших членів сім'ї.

Можливі декілька варіантів перебігу XTE:

1. Прогресуючий: прогресування симптомів протягом двох років

2. Стаціонарний: відсутність прогресування симптомів протягом двох років.

3. Флуктуючий: з періодами погіршення і поліпшення стану.

Згідно з класифрікацією А. С. McKee et al. (2016) [18], виділяють 3 стадії ХTЕ. У І стадії хвороба перебігає безсимптомно або пацієнт скаржиться на легкий десіцит короткотривалої пам'яті та депресивні симптоми, проявляє легку агресію.

У II стадії XTE настрій та поведінкові симптоми можуть включати в себе спалахи агресії та більш тяжкі депресивні симптоми.

У III стадії пацієнти зазвичай мають більше когнітивного дефіциту, включаючи втрату пам'яті, дефіцит виконавчої функції, візуально-просторову диссрункцію та апатію.

У IV стадії пацієнти мають виражені розлади мови, психотичні симптоми, включаючи параною, руховий дефріцит та паркінсонізм.

Дещо інший підхід до аналізу клінічної картини застосували R. A. Stern et al. [27], розподіливши клінічні симптоми на 2 різних підтипи. Перший підтип відображав в основному зміни настою та поведінкові розлади, а другий - переважно когнітивні. Однак такий підхід зазнав критики, оскільки у більшості пацієнтів із першим підтипом у міру прогресування захворювання розвивався когнітивний дефіцит та порівняно небагато пацієнтів когнітивної групи проявляли зміни настрою чи поведінки.

Метааналіз 158 досліджень дозволив A. Gardner et al. [31] розподілити клінічні симптоми XTE на «класичні» та «сучасні». Тоді як «класичні» симптоми XTE, як правило, включали дизартрію, рухові порушення та пізнє прогресування когнітивного дефіциту, в «сучасній» картині XTE з'явилися нервово-психічні симптоми, такі, як депресія, параноя, соціальна ізоляція тощо. Пізнавальний дефіцит з'являвся пізніше.

Таким чином, пошук консенсусу щодо клінічної класифрікації ХTE триває.

Із зростанням числа діагностованих випадків XTE виникає низка викликів та критичних питань, які потребують вирішення. Триває пошук діагностичних критеріїв, які дозволять не лише прижиттєво підтвердити діагноз ХТЕ, але і встановити маркери (нейрональної, аксональної та астрогліальної травм), що прогнозуватимуть ризик розвитку нейродегенеративної патології після ЧМТ [32].

Низка досліджень зосереджена на пошуку характерних ознак ушкодження головного мозку при проведенні ПЕТ [33-35], МРТ (дифузійному, структурному, фрункціональному, спектроскопії) [36, 37], як «віртуальної біопсії» для діагностики ХTЕ.

Теорія «когнітивного резерву» стверджує, що повторювана нейротравма призводить до зменшення когнітивного резерву та пришвидшення розвитку основних нейродегенеративних порушень [38], що вказує на схожість ХTЕ та хвороби Альцгеймера [39]. Подібно до хвороби Альцгеймера, ізофрорми тау-протеїну при ХТЕ також складаються із суміші трьох повторних (3R) та чотирьох повторних (4R) ізоформ. Однак згідно з останнім звітом B. Falcon et al. [40], нитки тау у хворих на XTE також містять унікальну $\beta$-спіральну ділянку 3 гідрофробною порожниною, якої немає в мозку пацієнтів із хворобою Альцгеймера. Порожнина містить додатковий кофактор, який, як вважається, відіграє фрункціональну роль у поширенні тау. Автори припускають, що розташування включень тау в безпосередній близькості від кровоносних судин, $€$ результатом того, що кофрактор допомагає перетинати гематоенцефалічний бар'єр. Припускають, що власне кофрактор може бути потенційною терапевтичною ціллю в запобіганні розвитку ХTЕ.

Ще одним перспективним методом $€$ дослідження екзосом. Наявність в екзосомах білків, пов'язаних 3 нейродегенеративними змінами, такими, як амілоїд- $\beta$, $\alpha$-синуклеїн та фросорорильований тау, вказує на їх роль в ініціюванні та розпо- 
всюдженні патології. Екзосоми можуть перетинати гематоенцефалічний бар'єр та бути виділені з периферичних рідин (сироватки, слини, сечі) [41]. Однак механізми клітинної комунікації із залученням екзосом у мозку та їх роль у патології недостатньо вивчені.

Паралельно 3 дослідженнями епідеміології, клініки, патогенезу та розробкою ефективних методів прижиттєвої діагностики, проводиться робота 3 дослідження засобів терапії ХTЕ. В експерименті показано, що сальсалат (нестероїдний протизапальний препарат) інгібує опосередковане p-300 ацетилювання тау, поліпшуючи пізнання та зменшуючи атрофічні процеси в гіпокампі [42], пригнічує активацію мікроглії/макрофрагів та індукує гени, відповідальні за нейрогенез та нейропротекцію [43].

\section{СПИСОК ЛІТЕРАТУРИ}

1. Raquel C. Gardner. Epidemiology of mild traumatic brain injury and neurodegenerative disease / Raquel C. Gardner, Kristine Yaffe // Molecular and Cellular Neuroscience. - 2015. - No. 66 (B). - P. 75-80.

2. Post-traumatic neurodegeneration and chronic traumatic encephalopathy / Daniel H. Daneshvar, Lee E. Goldstein, Patrick T. Kiernan [et al.] // Molecular and Cellular Neuroscience. - 2015. - No. 66 (B). - P. 81-90.

3. Martland H. Dementia pugilistica // JAMA. - 1928. No. 91. - P. 364-365.

4. Jordan B. D. The clinical spectrum of sport-related traumatic brain injury // Nat. Rev. Neurol. - 2013. - No. 9. - P. 222-230.

5. Victoroff J. Traumatic encephalopathy: review and provisional research diagnostic criteria // Neuro Rehabilitation. - 2013. - No. 32. - P. 211-224.

6. Clinical subtypes of chronic traumatic encephalopathy: literature review and proposed research diagnostic criteria for traumatic encephalopathy syndrome / P. H. Montenigro, C. M. Baugh, D. H. Daneshvar [et al] // Alzheimers Res. Ther. - 2014. - No. 6. - P. 68.

7. A clinical approach to the diagnosis of traumatic encephalopathy syndrome: a review / N. Reams, J. T. Eckner, A. A. Almeida [et al.] // JAMA Neurol. - 2016. - No. 73. - P. 743-749.

8. The utility of clinical criteria in patients with chronic traumatic encephalopathy / M. Laffey, A. J. Darby, M.G. Cline, E. Teng [et al.] // NeuroRehabilitation. - 2018. No. 43. - P. 431-441.

9. Weir D. R. National Football League Player Care Foundation: Study of Retired NFL Players / D. R. Weir, J. Jackson // Institute for Social Research. - 2009. - P. 56.

10. Chronic traumatic encephalopathy pathology in a neurodegenerative disorders brain bank / K. F. Bieniek, O. A. Ross, K. A. Cormier [et al.] // Acta Neuropathol. 2015. - No. 130. - P. 877-889.

11. Concussion, microvascular injury, and early tauopathy in young athletes after impact head injury and an impact concussion mouse model / C. A. Tagge, A. M. Fisher, O. V. Minaeva [et al.] // Brain. - 2018. -No. 141. - P. 422-458.

12. Blaylock R. L. Chapter 3. Immunoexcitotoxicity as a Central mechanism of chronic traumatic encephalopathy
Досліджується терапевтична еорективність метиленового синього [44], моноклональних антитіл [45].

\section{ВИСНОВКИ}

Незважаючи на майже столітню історію вивчення XTE, з часом кількість питань, які потребують вирішення, - зростає. Так, основними перспективними напрямками є: продовження епідеміологічних досліджень для визначення захворюваності та поширеності XTE у загальній популяції; ретельне клінічне френотипування 3 метою вироблення критеріїв клінічного та патологічного консенсусу; ідентифрікація біомаркерів у сироватці крові для ранньої діагностики; ідентиорікація оракторів ризику; генетичні дослідження для кращого розуміння генетичної архітектури ХТЕ.

- a unifying hypothesis / R. L. Blaylock, M. J. Maroon // Biomark Traum Brain Injury RSC Drug Discov. - 2011. No. 2. - P. 45-65.

13. Correlates of post-traumatic stress symptoms and growth in cancer patients: a systematic review and metaanalysis / L. K. Shand, S. Cowlishaw, J. E. Brooker [et al.] // Psycho-oncology. - 2015. - No. 24 (6). - P. 624-634.

14. Rapid accumulation of endogenous tau oligomers in a rat model of traumatic brain injury / B. E. Hawkins, S. Krishnamurthy, D. L. Castillo-Carranza [et al.] // J. Biol. Chem. - 2013. - No. 288. - P. 17042-17050.

15. The effects of mild closed head injuries on tauopathy and cognitive deficits in rodents: Primary results in wild type and rTg4510 mice, and a systematic review / A. D. Bachstetter, J. M. Morganti, C. N. Bodnar [et al.] // Experimental Neurology. - 2020. - No. 326. - P. 113-180.

16. Omalu BI. Chronic traumatic encephalopathy // Prog. Neurol. Surg. - 2014. - No. 28. - P. 38-49.

17. The neuropathology of chronic traumatic encephalopathy / A. C. McKee, T. D. Stein, P. T. Kiernan, V. E. Alvarez // Brain Pathol. - 2015. - No. 25. - P. 350-364.

18. The first NINDS/NIBIB consensus meeting to define neuropathological criteria for the diagnosis of chronic traumatic encephalopathy / A. C. McKee, N. J. Cairns, D. W. Dickson [et al.] // Acta Neuropathol. - 2016. No. 131. - P. 75-86.

19. Erratum to: the association between whitematter tract abnormalities, and neuropsychiatric and cognitive symptoms in retired professional football players with multiple concussions / N. Multani, R. Goswami, M. Khodadadi [et al.] // J. Neurol. - 2016. - No. 263. - P. 1342.

20. White matter signal abnormalities in former National Football League players / M. L. Alosco, I. K. Koerte, Y. Tripodis [et al.] // Alzheimer Dement. - 2018. - No. 10. P. 56-65.

21. Microstructural maturation of the human brain from childhood to adulthood / C. Lebel, L. Walker, A. Leemans, A. [et al.] // Neurolmage. - 2008. - No. 40. - P. 1044-1055.

22. Developmental trajectories of amygdala and hippocampus from infancy to early adulthood in healthy individuals / A. Uematsu, M. Matsui, C. Tanaka [et al.] // PLoS ONE. - 2012. - No. 7. - e46970. 
23. Age at first exposure to football is associated with altered corpus callosum white matter microstructure in former professional football players / J. M. Stamm, I. K. Koerte, M. Muehlmann [et al.] // J. Neurotrauma. 2015. - No. 32. - P. 1768-1776.

24. Age at first exposure to repetitive head impacts is associated with smaller thalamic volumes in former professional American Football Players / V. Schultz, R. A. Stern, Y. Tripodis [et al.] // J. Neurotrauma. - 2018. No. 35. - P. 278-285.

25. Prevalence of apolipoprotein E4 genotype and homozygotes (APOE e4/4) among patients diagnosed with Alzheimer's disease: a systematic review and metaanalysis / A. Ward, S. Crean, C. J. Mercaldi [et al.] // Neuroepidemiology. - 2012. - No. 38. - P. 1-17.

26. Stern Y. Cognitive reserve in ageing and Alzheimer's disease // Lancet Neurol. - 2012. - No. 11. - P. 1006-1012.

27. Clinical presentation of chronic traumatic encephalopathy / R. A. Stern, D. H. Daneshvar, C. M. Baugh [et al.] // Neurology. - 2013. - No. 81. - P. 1122-1129.

28. Jordan B. D. The clinical spectrum of sport-related traumatic brain injury / B. D. Jordan // Nat. Rev. Neurol. 2013. - No. 9. - P. 222-230.

29. Mez J. Chronic traumatic encephalopathy: where are we and where are we going? / J. Mez, R. A. Stern, A. C. McKee // Curr. Neurol. Neurosci. Rep. - 2013. No. 13 (12). - P. 407.

30. Clinical subtypes of chronic traumatic encephalopathy: literature review and proposed research diagnostic criteria for traumatic encephalopathy syndrome / P. H. Montenigro, C. M. Baugh, D. H. Daneshvar [et al.] // Alzheimer's Research and Therapy. - 2014. - No. 6. - P. 68-85.

31. Gardner A. Chronic traumatic encephalopathy in sport: a systematic review / A. Gardner, G. L. Iverson, P. McCrory // Br. J. Sports Med. - 2014. - No. 48. - P. 84-90.

32. Zetterberg $\mathrm{H}$. Fluid markers of traumatic brain injury / H. Zetterberg, K. Blennow // Molecular and Cellular Neuroscience. - 2015. - No. 66 (B). - P. 99-102.

33. A systematic review of positron emission tomography of tau, amyloid beta, and neuroinflammation in chronic traumatic encephalopathy: the evidence to-date / B. Lee, M. Leavitt, C. Bernick [et al.] // J. Neurotrauma. - 2018. - No. 35 (17). - P. 2015-2024.

34. Tau positron-emission tomography in former National Football League players / R. A. Stern, C. H. Adler,

\section{REFERENCES}

1. Raquel C Gardner, Kristine Yaffe. Epidemiology of mild traumatic brain injury and neurodegenerative disease. Molecular and Cellular Neuroscience. 2015;66(B): 75-80.

2. Daniel H Daneshvar, Lee E Goldstein, Patrick $T$ Kiernan, Thor D Stein, Ann C McKee, Post-traumatic neurodegeneration and chronic traumatic encephalopathy. Molecular and Cellular Neuroscience. 2015;66(B): 81-90,

3. Martland H. Dementia pugilistica. JAMA. 1928;91: 364-65.

4. Jordan BD. The clinical spectrum of sport-related traumatic brain injury. Nat Rev Neurol. 2013;9: 222-30.

5. Victoroff J. Traumatic encephalopathy: review and provisional research diagnostic criteria. NeuroRehabilitation. 2013;32: 211-24.
K. Chen [et al.] // The New England Journal of Medicine. 2019. - No. 380 (18). - P. 1716-1725.

35. Tau positron emission tomographic findings in a former US football player with pathologically confirmed chronic traumatic encephalopathy / W. G. Mantyh, S. Spina, A. Lee [et al.] // JAMA neurology. - 2020. No. 77 (4). - P. 517-521.

36. Magnetic resonance spectroscopy as a biomarker for chronic traumatic encephalopathy / M. Alosco, J. Jarnagin, B. Rowland [et al.] // Semin. Neurol. - 2017. No. 37. - P. 503-509.

37. Ruprecht R. Systematic review on the characterization of chronic traumatic encephalopathy by MRI and MRS / R. Ruprecht, E. Scheurer, C. Lenz // J. Magn. Reson. Imaging. - 2019. - No. 49. - P. 212-228.

38. A critical review of chronic traumatic encephalopathy / G. L. Iverson, A. J. Gardner, P. McCrory [et al.] // Neurosci. Biobehav. Rev. - 2015. - No. 56. - P. 276-293.

39. Randolph C. Chronic traumatic encephalopathy is not a real disease // Arch. Clin. Neuropsychol. - 2018. No. 3. - P. 644-648.

40. Novel tau filament fold in chronic traumatic encephalopathy encloses hydrophobic molecules / B. Falcon, J. Zivanov, W. Zhang [et al.] // Nature. - 2019. No. 568. - P. 420-423.

41. Extracellular vesicle proteins and microRNAs as biomarkers for traumatic brain injury / V. A. Guedes, C. Devoto, J. Leete [et al.] // Front Neurol. - 2020. No 11. - P. 663.

42. Role of tau acetylation in Alzheimer's disease and chronic traumatic encephalopathy: the way forward for successful treatment / B. Lucke-Wold, K. Seidel, R. Udo [et al.] // J. Neurol Neurosurg. - 2017. - No. 4. - P. 140.

43. Salsalate treatment following traumatic brain injury reduces inflammation and promotes a neuroprotective and neurogenic transcriptional response with concomitant functional recovery / M. Lagraoui, G. Sukumar, J. R. Latoche [et al.] // Brain Behav. Immun. - 2017. - No. 61. - P. 96-109.

44. A dual pathogenic mechanism links tau acetylation to sporadic tauopathy / H. Trzeciakiewicz, J.H. Tseng, C.M. Wander [et al.] // Sci. Rep. - 2017. - No. 7. - P. 44102.

45. Potential novel approaches to understand the pathogenesis and treat Alzheimer's disease / E. Drummond, F. Goni, S. Liu [et al.] // J. Alzheimers Dis. - 2018. - No. 64 (Suppl. 1). - P. 299-312.

6. Montenigro $\mathrm{PH}$, Baugh $\mathrm{CM}$, Daneshvar $\mathrm{DH}$, Mez J, Budson AE, Au R, et al. Clinical subtypes of chronic traumatic encephalopathy: literature review and proposed research diagnostic criteria for traumatic encephalopathy syndrome. Alzheimers Res. Ther. 2014;6: 68

7. Reams N, Eckner JT, Almeida AA, Aagesen AL, Giordani B, Paulson $\mathrm{H}$, et al. A clinical approach to the diagnosis of traumatic encephalopathy syndrome: a review. JAMA Neurol.2016;73: 743-9.

8. Laffey M, Darby AJ, Cline MG, Teng E, Mendez MF. The utility of clinical criteria in patients with chronic traumatic encephalopathy. NeuroRehabilitation. 2018;43: 431-41.

9. Weir DR, Jackson J. National Football League Player 
Care Foundation: Study of Retired NFL Players. Institute for Social Research;. 2009;56

10. Bieniek KF, Ross OA, Cormier KA, Walton RL, Soto-Ortolaza A, Johnston AE, et al. Chronic traumatic encephalopathy pathology in a neurodegenerative disorders brain bank. Acta neuropathol. 2015;130: 877-89.

11. Tagge CA, Fisher AM, Minaeva OV, GaudreauBalderrama A, Moncaster JA, Zhang XL, et al. Concussion, microvascular injury, and early tauopathy in young athletes after impact head injury and an impact concussion mouse model. Brain. 2018;141: 422-58.

12. Blaylock RL, Maroon MJ. Chapter 3. Immunoexcitotoxicity as a central mechanism of chronic traumatic encephalopathy - a unifying hypothesis. Biomark Traum Brain Injury RSC Drug Discov. 2011;2: 45-65.

13. Shand LK, Cowlishaw S, Brooker JE, Burney $S$ \& Ricciardelli LA. Correlates of post-traumatic stress symptoms and growth in cancer patients: a systematic review and meta-analysis. Psycho-oncology. 2015;24(6): 624-34.

14. Hawkins BE, Krishnamurthy S, Castillo-Carranza DL, Sengupta U, Prough DS, Jackson GR et al. Rapid accumulation of endogenous tau oligomers in a rat model of traumatic brain injury. J Biol. Chem. 2013;288: 17042-50.

15. Bachstetter AD, Morganti JM, Bodnar CN, Webster SJ, Higgins EK, Roberts KN et al. The effects of mild closed head injuries on tauopathy and cognitive deficits in rodents: Primary results in wild type and rTg4510 mice, and a systematic review. Experimental neurology. 2020;326: 113180.

16. Omalu BI. Chronic traumatic encephalopathy. Prog Neurol Surg. 2014;28: 38-49.

17. McKee AC, Stein TD, Kiernan PT, Alvarez VE. The neuropathology of chronic traumatic encephalopathy. Brain Pathol. 2015;25: 350-64.

18. McKee AC, Cairns NJ, Dickson DW, Folkerth RD, Keene CD, Litvan I, et al. The first NINDS/NIBIB consensus meeting to define neuropathological criteria for the diagnosis of chronic traumatic encephalopathy. Acta Neuropathol. 2016;131: 75-86.

19. Multani N, Goswami R, Khodadadi M, Ebraheem A, Davis KD, Tator $\mathrm{CH}$, et al. Erratum to: the association between white-matter tract abnormalities, and neuropsychiatric and cognitive symptoms in retired professional football players with multiple concussions. J Neurol. 2016;263: 1342.

20. Alosco ML, Koerte IK, Tripodis Y, Mariani M, Chua AS, Jarnagin J, et al. White matter signal abnormalities in former National Football League players. Alzheimer Dement. 2018;10: 56-65.

21. Lebel C, Walker L, Leemans A, Phillips L, Beaulieu C. Microstructural maturation of the human brain from childhood to adulthood. Neurolmage. 2008;40: 1044-55.

22. Uematsu A, Matsui M, Tanaka C, Takahashi T, Noguchi K, Suzuki M, et al. Developmental trajectories of amygdala and hippocampus from infancy to early adulthood in healthy individuals. PLoS ONE. 2012;7: e46970.

23. Stamm JM, Koerte IK, Muehlmann M, Pasternak $\mathrm{O}$, Bourlas AP, Baugh $\mathrm{CM}$, et al. Age at first exposure to football is associated with altered corpus callosum white matter microstructure in former professional football players. J Neurotrauma. 2015;32: 1768-76.

24. Schultz V, Stern RA, Tripodis Y, Stamm J, Wrobel $P$, Lepage $C$, et al. Age at first exposure to repetitive head impacts is associated with smaller thalamic volumes in former professional American Football Players. J Neurotrauma. 2018;35: 278-85.

25. Ward A, Crean S, Mercaldi CJ, Collins JM, Boyd D, Cook MN, et al. Prevalence of apolipoprotein E4 genotype and homozygotes (APOE e4/4) among patients diagnosed with Alzheimer's disease: a systematic review and metaanalysis. Neuroepidemiology. 2012;38: 1-17.

26. Stern Y. Cognitive reserve in ageing and Alzheimer's disease. Lancet Neurol. 2012;11: 1006-12.

27. Stern RA, Daneshvar DH, Baugh CM, Seichepine DR, Montenigro $\mathrm{PH}$, RileyDO, et al. Clinical presentation of chronic traumatic encephalopathy. Neurology. 2013;81: 1122-9.

28. Jordan BD. The clinical spectrum of sport-related traumatic brain injury. Nat Rev Neurol. 2013;9: 222-30.

29. Mez J, Stern RA, McKee AC. Chronic traumatic encephalopathy: where are we and where are we going? Curr Neurol Neurosci Rep. 2013;13(12): 407.

30. Montenigro $\mathrm{PH}$, Baugh CM, Daneshvar $\mathrm{DH}, \mathrm{Mez} \mathrm{J}$, Budson $A E$, Rhoda $A$, et al. Clinical subtypes of chronic traumatic encephalopathy: literature review and proposed research diagnostic criteria for traumatic encephalopathy syndrome. Alzheimer's Research and Therapy. 2014;6: 6885.

31. Gardner A, Iverson GL, McCrory P. Chronic traumatic encephalopathy in sport: a systematic review. $\mathrm{Br}$ J Sports Med. 2014;48: 84-90.

32. Henrik Zetterberg, Kaj Blennow. Fluid markers of traumatic brain injury. Molecular and Cellular Neuroscience. 2015;66(B): 99-102.

33. LeeBG, LeavittMJ,BernickCB, LegerGC, RabinoviciG Banks SJ. A Systematic Review of Positron Emission Tomography of Tau, Amyloid Beta, and Neuroinflammation in Chronic Traumatic Encephalopathy: The Evidence To Date. Journal of Neurotrauma. 2018;35(17): 2015-24.

34. Stern RA, Adler $\mathrm{CH}$, Chen K, Navitsky M, Luo J, Dodick DW, et al. Tau positron-emission tomography in former National Football League players. The New England journal of medicine. 2019;380(18): 1716-25

35. Mantyh WG, Spina S, Lee A, laccarino L, Soleimani-Meigooni D, Tsoy E et al. Tau positron emission tomographic findings in a former US football player with pathologically confirmed chronic traumatic encephalopathy. JAMA neurology. 2020;77(4): 517-21.

36. Alosco M, Jarnagin J, Rowland B, Liao H, Stern R, Lin A. Magnetic resonance spectroscopy as a biomarker for chronic traumatic encephalopathy. Semin Neurol. 2017;37: 503-9.

37. Ruprecht R, Scheurer E, Lenz C. Systematic review on the characterization of chronic traumatic encephalopathy by MRI and MRS. J Magn Reson Imaging. 2019;49: 212-28.

38. Iverson GL, Gardner AJ, McCrory P, Zafonte R Castellani RJ. A critical review of chronic traumatic encephalopathy. Neurosci Biobehav Rev. 2015;56: 276-93.

39. Randolph C. Chronic traumatic encephalopathy is not a real disease. Arch Clin Neuropsychol. 2018;3: 644-8.

40. FalconB,ZivanovJ,ZhangW, MurzinAG, GarringerHJ, Vidal $\mathrm{R}$, et al. Novel tau filament fold in chronic traumatic encephalopathy encloses hydrophobic molecules. Nature. 2019;568: 420-3.

41. Guedes VA, Devoto C, Leete J, Sass D, Acott JD, Mithani $S$ et al. Extracellular vesicle proteins and microRNAs 
as biomarkers for traumatic brain injury. Front Neurol. 2020;11: 663.

42. Lucke-Wold B, Seidel K, Udo R, Omalu B, Ornstein M, Nolan R, et al. Role of tau acetylation in Alzheimer's disease and chronic traumatic encephalopathy: the way forward for successful treatment. J Neurol Neurosurg. 2017;4: 140.

43. Lagraoui M, Sukumar G, Latoche JR, Maynard SK, Dalgard CL, Schaefer BC. Salsalate treatment following traumatic brain injury reduces inflammation and promotes a neuroprotective and neurogenic transcriptional response with concomitant functional recovery. Brain Behav Immun. 2017;61: 96-109.

44. Trzeciakiewicz H, Tseng JH, Wander CM, Madden V, Tripathy A, Yuan CX, et al. A dual pathogenic mechanism links tau acetylation to sporadic tauopathy. Sci Rep. 2017;7: 44102.

45. Drummond E, Goni F, Liu S, Prelli F, Scholtzova H, Wisniewski T. Potential novel approaches to understand the pathogenesis and treat Alzheimer's disease. J Alzheimer's Dis JAD. 2018;64(1): 299-312. 